\title{
Development of multilayer constructs for tissue engineering
}

Citation for published version (APA):

Bettahalli, N. M. S., Groen, N., Steg, H., Unadkat, H., de Boer, J., van Blitterswijk, C. A., Wessling, M., \& Stamatialis, D. (2014). Development of multilayer constructs for tissue engineering. Journal of Tissue Engineering and Regenerative Medicine, 8(2), 106-119. https://doi.org/10.1002/term.1504

Document status and date:

Published: 01/02/2014

DOI:

10.1002/term.1504

Document Version:

Publisher's PDF, also known as Version of record

Document license:

Taverne

Please check the document version of this publication:

- A submitted manuscript is the version of the article upon submission and before peer-review. There can be important differences between the submitted version and the official published version of record.

People interested in the research are advised to contact the author for the final version of the publication, or visit the DOI to the publisher's website.

- The final author version and the galley proof are versions of the publication after peer review.

- The final published version features the final layout of the paper including the volume, issue and page numbers.

Link to publication

\footnotetext{
General rights rights.

- You may freely distribute the URL identifying the publication in the public portal. please follow below link for the End User Agreement:

www.umlib.nl/taverne-license

Take down policy

If you believe that this document breaches copyright please contact us at:

repository@maastrichtuniversity.nl

providing details and we will investigate your claim.
}

Copyright and moral rights for the publications made accessible in the public portal are retained by the authors and/or other copyright owners and it is a condition of accessing publications that users recognise and abide by the legal requirements associated with these

- Users may download and print one copy of any publication from the public portal for the purpose of private study or research.

- You may not further distribute the material or use it for any profit-making activity or commercial gain

If the publication is distributed under the terms of Article $25 \mathrm{fa}$ of the Dutch Copyright Act, indicated by the "Taverne" license above, 


\title{
Development of multilayer constructs for tissue engineering
}

\author{
NMS Bettahalli ${ }^{1}$, N Groen ${ }^{1,2}$, H Steg $^{1}$, H Unadkat $^{2}$, de Boer $^{2}$, CA van Blitterswijk ${ }^{2}$, M Wessling ${ }^{1,3}$ and \\ D Stamatialis ${ }^{1,4 *}$ \\ ${ }^{1}$ Membrane Technology Group, Faculty of Science and Technology, PO Box 217, 7500 AE Enschede, The Netherlands \\ ${ }^{2}$ Dept. of Tissue Regeneration, Faculty of Science and Technology, PO Box 217, 7500 AE Enschede, The Netherlands \\ ${ }^{3}$ RWTH Aachen University, Chemische Verfahren Technik (CVT), 52064 Aachen, Germany \\ ${ }^{4}$ Biomaterials Science and Technology, Faculty of Science and Technology, PO Box 217, 7500 AE Enschede, The Netherlands
}

\begin{abstract}
The rapidly developing field of tissue engineering produces living substitutes that restore, maintain or improve the function of tissues or organs. In contrast to standard therapies, the engineered products become integrated within the patient, affording a potentially permanent and specific cure of the disease, injury or impairment. Despite the great progress in the field, development of clinically relevantly sized tissues with complex architecture remains a great challenge. This is mostly due to limitations of nutrient and oxygen delivery to the cells and limited availability of scaffolds that can mimic the complex tissue architecture. This study presents the development of a multilayer tissue construct by rolling pre-seeded electrospun sheets [(prepared from poly (1-lactic acid) (PLLA) seeded with C2C12 pre-myoblast cells)] around a porous multibore hollow fibre (HF) membrane and its testing using a bioreactor. Important elements of this study are: 1) the medium permeating through the porous walls of multibore HF acts as an additional source of nutrients and oxygen to the cells, which exerts low shear stress (controllable by trans membrane pressure); 2) application of dynamic perfusion through the HF lumen and around the 3D construct to achieve high cell proliferation and homogenous cell distribution across the layers, and 3) cell migration occurs within the multilayer construct (shown using pre-labeled C2C12 cells), illustrating the potential of using this concept for developing thick and more complex tissues. Copyright (C) 2012 John Wiley \& Sons, Ltd.
\end{abstract}

Received 24 February 2011; Revised 5 December 2011; Accepted 30 January 2012

Keywords hollow fibre; electro spinning; multilayer scaffold; bioreactor; tissue engineering

\section{Introduction}

*Correspondence to: D Stamatialis, Biomaterials Science and Technology, Faculty of Science and Technology, PO Box 217, 7500 AE Enschede, The Netherlands. Phone: +31 53489 4675, Fax:+31 53489 2155. E-mail: d.stamatialis@utwente.nl

All from MIRA Institute for Biomedical Technology and Technical Medicine, University of Twente

Abbreviations used: CM-DiI, 1,1'-dioctadecyl--3,3,3',3'tetramethylindocarbocyanine per chlorate; CM-DiO, 3,3 dioctadecyloxacarbocyanine per chlorate; D-MEM; Dulbecco's Modified Eagle's Medium; ECM; extra cellular matrix; ES, electro spun sheet or mesh; ESP; electro spinning process; FBS; fetal bovine serum; HF; hollow fibre; MES; multilayer cell-electrospun construct; PBS; phosphate buffered saline $(\mathrm{pH}=7.3)$; PBT; poly(butylene terephthalate), PCL; poly(caprolactone), PEOT; poly(ethylene glycol terephthalate); PLLA; poly (L lactic acid); SEM, scanning electron microscope
Current efforts to induce healing and regeneration of damaged tissue are directed towards improving existing cell therapies and developing new tissue engineering strategies. Small defects can be successfully treated with autologous cells (autograft) (Baiguera et al., 2010; Brayfield et al., 2010; Peterson et al., 2000; Sala et al., 2009; Zhang et al., 2009). However, large defects and most tissues and organs are usually composed of multiple layers of various cell types; cells with asymmetric functions (liver cells) and of varying extracellular matrix (ECM). The cells and ECM are arranged in an elaborate and hierarchical order to achieve specific functions and to mutually regulate cellular activity by soluble bioactive molecules, cell-cell or cell-ECM interactions (Fukuhara et al., 2003; Kleinman et al., 2003; Stahl et al., 2004). 
The elaborate structure also provides individual cells with a defined microenvironment where cells experience specific cues and show corresponding responses towards tissue function. To maintain the proper cell phenotype in $3 \mathrm{D}$ tissue engineering, a biomimetic design is required to replicate ECM, seeding/infiltration of cells onto a biomaterial scaffold and culturing the seeded scaffold with adequate nutrient supply (Goldstein and Christ 2009; Martin et al., 2004; Wendt et al., 2009).

Recent understanding that ECM is a natural 3D cell supporter with a complex ultra-structure (Stevens and George 2005; Wnek et al., 2003) often determines the direction for scaffold design. To this end, electrospinning process (ESP) has been used to fabricate a nonwoven mesh as scaffold to mimic collagen fibrils in natural tissue matrix (Pham et al., 2006a) with fibre size in the micro/nanometer scale (Reneker et al., 2006; Theron et al., 2004; Tuzlakoglu et al., 2005; Zussman et al., 2003). The fibrous mesh also attributes in spatial arrangement (random or aligned), high porosity, mechanical property and increased surface area (Neves et al., 2007; Pham et al., 2006a; Pham et al., 2006b). Some challenges with the application of the ESP meshes are recognized, especially the difficulty of cell migration/infiltration into thick meshes and the cellular spatial arrangement for single or multiple cell types. Natural tissues vary from single cell types with rather uniform organization such as muscle tissue (Langelaan et al., 2010), neuritis (Morelli et al., 2010) or gradient organization such as in cartilage (Woodfield et al., 2005) to complex layer-by-layer multicellular organization such as in blood vessels (Ju et al., 2010; Vaz et al., 2005) and skin (Yang et al., 2009). Mimicking these multilayer multicellular arrangements and providing optimal supply of nutrients and oxygen to the entire $3 \mathrm{D}$ construct is a major challenge.

Recently, media perfusion bioreactor systems have been developed to improve mass transport throughout 3D tissue engineered constructs (Pei et al., 2002; Porter et al., 2005; Janssen et al., 2006; Janssen et al., 2010). However, problems arise in large constructs where in order to achieve delivery of nutrients and oxygen into the interior, medium perfusion occurs at high flowrates, inducing high shear stress to the cells in the periphery. Some recent attempts to address this issue incorporated porous hollow fibre membranes into the scaffolds or by using fibre itself as scaffold (Abdullah and Das 2007; De Bartolo et al., 2009; Ye et al., 2006; Stamatialis et al., 2008). In addition to the standard perfusion across the scaffold, additional perfusion occurs via the hollow fibre (De Bartolo et al., 2007; De Bartolo et al., 2009; Ellis and Chaudhuri 2007). Despite these promising results, development of multilayer thick tissues remains a challenge.

In this study, we propose the development of a multilayer tubular construct by rolling electro-spun (ES) PLLA sheets around a multibore hollow fibre membrane. We hypothesize that the multibore membrane can deliver nutrients in a very controlled manner with no shear stress to the cells. The developed construct was cultured statically and dynamically in a bioreactor. In fact, for the dynamic culture studies, we compared a medium flow via the fibre alone and dual flow combining the flow through and around the construct and via the fibre. In addition, by using pre-labeled cells, we showed that within our construct, cell migration occurred. For the complete evaluation of this concept, we used a combination of techniques: scanning electron microscopy and cell staining for showing cell distribution and DNA assay for quantitative determination of cell proliferation within the construct.

\section{Materials and methods}

\subsection{Electrospun (ES) sheet fabrication and characterization}

ES sheets were fabricated using poly(L-lactic acid) (PLLA) (mol wt. $1.6 \times 10^{5} \mathrm{~g} / \mathrm{mol}$ ) of various concentrations: 10 , 12,13 and $15 \mathrm{wt} \%$ dissolved in 1,3-dioxane (Sigma-Aldrich, $97 \%$ purity), kindly provided by Prof. Dr. D. Grijpma, Biomaterials Science and Technology group, University of Twente, The Netherlands. The PLLA solution was loaded into a 5-ml syringe mounted on a syringe pump and fed into a hypodermic metal needle (18G medical grade syringe needle) at a constant rate ranging from 0.5 to $10 \mathrm{ml} / \mathrm{h}$ (Figure 1). The needle was charged by connecting to a 15-KV generator source to initiate the electrostatic field for electrospinning. Grounded aluminum foil of $10 \mathrm{~cm} \times 10 \mathrm{~cm}$ was placed 10 to $25 \mathrm{~cm}$ apart from the tip of the needle to collect the fibres in the form of a non-woven mesh for

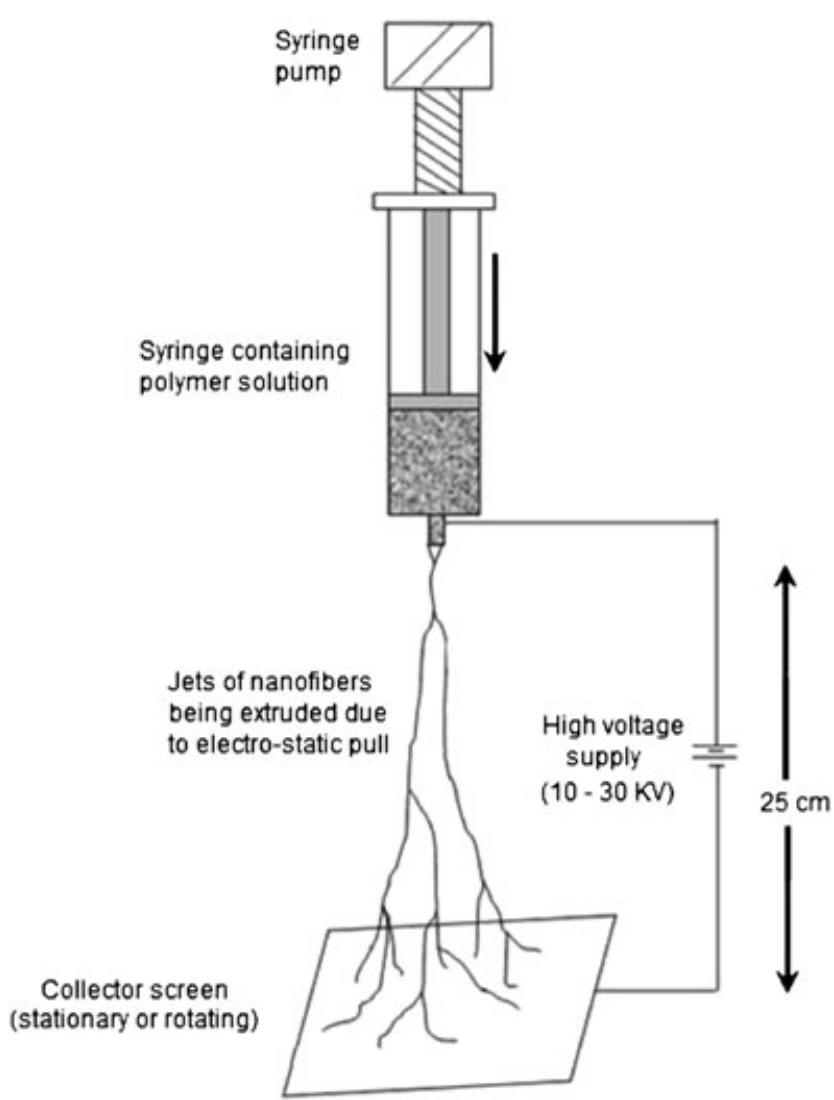

Figure 1. Schematic representation of electro spinning setup 
$30 \mathrm{~min}$. The setup was built inside a controlled temperature box $\left(20^{\circ} \mathrm{C}\right)$ to maintain constant humidity. The ES sheets were then dried in airflow chamber for at least 2 days to evaporate residual solvents.

\subsection{Multibore hollow fibre module assembly and treatment}

The commercially available multibore HF membrane (Inge AG, Greifenberg, Germany) made of modified poly (ether sulfone) was used for medium permeation and support for ES sheets. These multibore fibre consisted of 7 bores (0.9 $\mathrm{mm}$ inner diameter) arranged symmetrically to form single fibres of $4 \mathrm{~mm}$ diameter (see detail fibre characteristics later) and have proven biocompatibility (De Bartolo et al., 2007) and expected to efficiently deliver controllable nutrients to the cells via the multiple bores. Approximately 12-cm long multibore HF modules were prepared manually by carefully inserting each end into an $8 \mathrm{~mm}$ polyethylene tube sealed with polyurethane glue such that a $2-\mathrm{cm}$ fibre surface was exposed for permeation at the middle of the module. HF modules were sterilized by pumping $70 \%$ ethanol at low pressure $(\sim 0.1$ bar) in a sterile environment through the fibre. Further, they were conditioned to remove any traces of ethanol or toxic components by pumping phosphate buffered saline (PBS) $(\mathrm{pH}=7.3)$ and proliferation medium, correspondingly.

\subsection{Characterization}

\subsubsection{Scanning electron microscopy (SEM)}

SEM images of the ES sheets and of the hollow fibres were obtained using a JEOL 5600LV scanning electron microscope at accelerating voltage of $5 \mathrm{kV}$. Samples were dried in a vacuum oven at $30^{\circ} \mathrm{C}$ overnight and then used for surface scan, whereas samples for cross-sectional observation were carefully fractured in liquid nitrogen. All samples were sputtered with gold ( $\sim 15$ to 20 nm-thick using a Balzer-Union SCD-040 sputtering device) before imaging.

\subsubsection{Multibore hollow fibre characterization}

Water permeance. Pure water permeance of the multibore HF was determined by pressurizing ultrapure water (18.2 MQcm, MilliQ) through the lumen of the HF (inside-out permeation). The experiments were carried out in a glass casing containing the multibore HF module, each prepared using an 8-mm polyethylene tube housing such that approximately $10 \mathrm{~cm}$ of HF was exposed to water (as explained above). The glass casing had side ports to collect the flowing permeate. Before measuring water permeance, fibres were pre-wetted by pumping water through the modules for at least $30 \mathrm{~min}$. The flux $\left[\left(\mathrm{J}\right.\right.$, in $\left.\mathrm{L} /\left(\mathrm{m}^{2} \mathrm{~h}\right)\right]$ through the membrane was measured at different trans-membrane pressures ranging between 0.02 to 0.3 bars at $20 \pm 2{ }^{\circ} \mathrm{C}$. The flux at each pressure was successively measured by collecting the permeating water for at least $30 \mathrm{~min}$. The pure water permeance in $\mathrm{L} /\left(\mathrm{m}^{2} \mathrm{~h}\right.$ bar) was calculated from the slope of flux versus trans-membrane pressure plot. The data presented in this work is an average of four different fibre modules.

Medium permeance. Proliferation medium permeance experiments were performed in sterile crossflow setup by pumping Dulbecco's Modified Eagle's Medium (DMEM, Gibco $^{\circledR}$, Invitrogen, Life Technologies Europe BV, Bleiswijk, Netherlands) supplemented with $10 \%$ fetal bovine serum (Invitrogen), $100 \mathrm{U} / \mathrm{ml}$ penicillin $\left(\mathrm{Gibco}^{\circledR}\right.$ ) and $100 \mu \mathrm{g} / \mathrm{ml}$ streptomycin $\left(\mathrm{Gibco}^{\circledR}\right.$ ) through the lumen of the HF. Medium permeance was measured at trans-membrane pressures ranging between 0.02 to 0.1 bar at $20 \pm 2{ }^{\circ} \mathrm{C}$. During the experiment the medium reservoir (feed) was stirred and pumped to the membrane module using a peristaltic pump with recirculation. The collected permeating medium and unfiltered medium was also used to statically culture mouse pre-myoblast (C2C12) cells in T-flask (T20) for comparison of cell proliferation rate.

\subsection{Electrospun sheet: multibore hollow fibre module assembly}

\subsubsection{Pre-seeded electrospun sheets}

Mouse pre-myoblasts C2C12 cells (harvested by Tissue Regeneration group, University of Twente, The Netherlands) were cultured in proliferation medium containing D-MEM supplemented with 10\% FBS (Invitrogen), $100 \mathrm{U} / \mathrm{ml}$ penicillin $\left(\right.$ Gibco $^{\circledR}$ ) and $100 \mu \mathrm{g} / \mathrm{ml}$ streptomycin $\left(\right.$ Gibco ${ }^{\circledR}$ ). Cells were initially plated in a T-flask for expansion at 2000 cells $/ \mathrm{cm}^{2}$ until they reached $70-80 \%$ confluence, after which they were trypsinized using $0.05 \%$ Trypsin in $1 \mathrm{mM}$ EDTA. The obtained C2C12 cells were aggregated, re-suspended in $200 \mu \mathrm{l}$ medium and $5 \times 10^{5}$ cells were subsequently seeded onto a $2 \mathrm{~cm} \times 6 \mathrm{~cm}$ ES sheet in a special culture plate which accommodated the ES sheet. The cells were allowed to attach for 1 day before rolling and subjecting to static or dynamic culture experiments.

\subsubsection{Cell-electrospun sheet rolling}

Two pre-seeded ES sheets after cultured statically for one day were rolled around the multibore HF forming four layers each around the multibore HF. The sheets were rolled in such a way that the cell-seeded surface faced the fibre surface. In total, eight layers of cell-ES sheet construct were formed by rolling two ES sheets. Sterile cotton threads ( $\sim 10 \mathrm{~cm}$ long for each end) were used to fasten the rolled sheets together and prevent unfolding of the layers (Figure 2b). The construct was immediately placed in proliferation medium before further culturing under static or dynamic conditions. Hereafter the multilayer constructs will be abbreviated as "MES construct". To maintain sterility, the MES construct was assembled inside a sterile 
flow cabinet using sterile surgical tongs. Subsequently for dynamic culture experiments, the MES constructs were placed in a sterile bioreactor and cultured as stated below.

\subsection{Cell culturing}

\subsubsection{Static culture}

MES constructs were statically cultured in T-flasks containing proliferation medium by immersing the whole construct in the medium. Samples were cultured for 3 and 7 days in a sterile incubator with proliferation medium refreshed every alternate day. The resulting samples were analysed using light and fluorescent microscopy and quantified by total DNA assay.

\subsubsection{Dynamic culture}

Dynamic cell culture within the glass bioreactor was performed using a perfusion system consisting of a medium reservoir (Laboratory Glass Specialist B.V, Ubbena, The Netherlands), FDA approved platinum cured silicon tubing (Masterflex, Applikon analytical B.V., Schiedam, The Netherlands), a multi-channel precision flow peristaltic pump (Watson-Marlow 205U, Delden, The Netherlands), click connectors (Applikon analytical B.V., Schiedam, The Netherlands) and a pressure sensor (Figure 2). The perfusion bioreactor system was built within a temperature, humidity- and $\mathrm{CO}_{2}$-controlled sterile incubator. A reservoir containing $100 \mathrm{ml}$ of proliferation medium was re-circulated to feed the cells for three days before refreshing. The medium pumped from the reservoir was oxygenated before entering

(a)

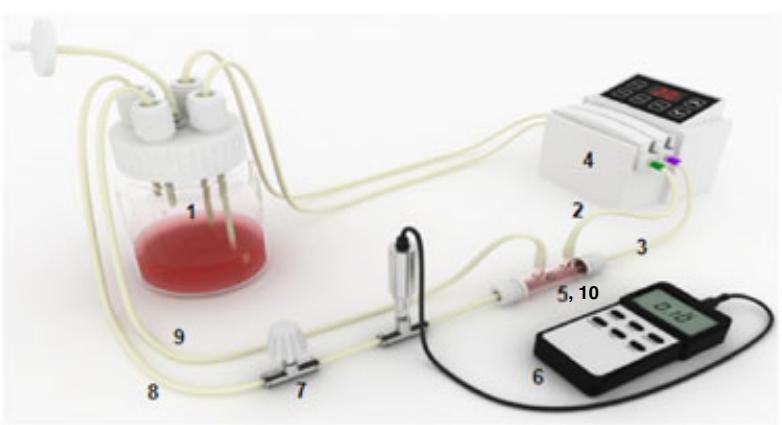

(1) Medium reservoir

(2) Medium flow in the module

(3) Medium flow through $\mathrm{HF}$

lumen

(4) Peristaltic pump

(5) Bioreactor chamber

(6) Pressure sensor

(7) Control valve

(8) Retentate recirculation

(9) Permeate recirculation

(10) Multilayer cell-ES module

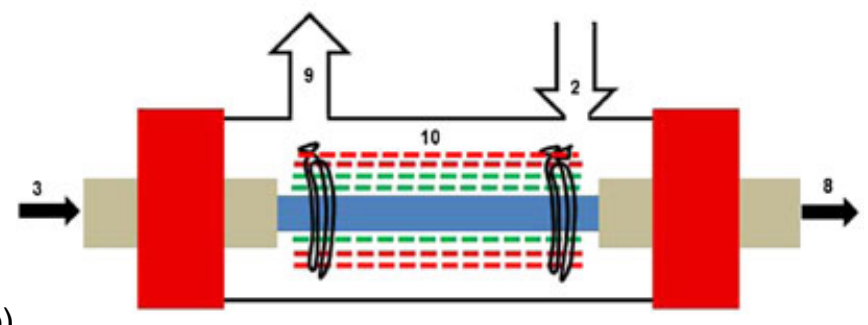

(b)

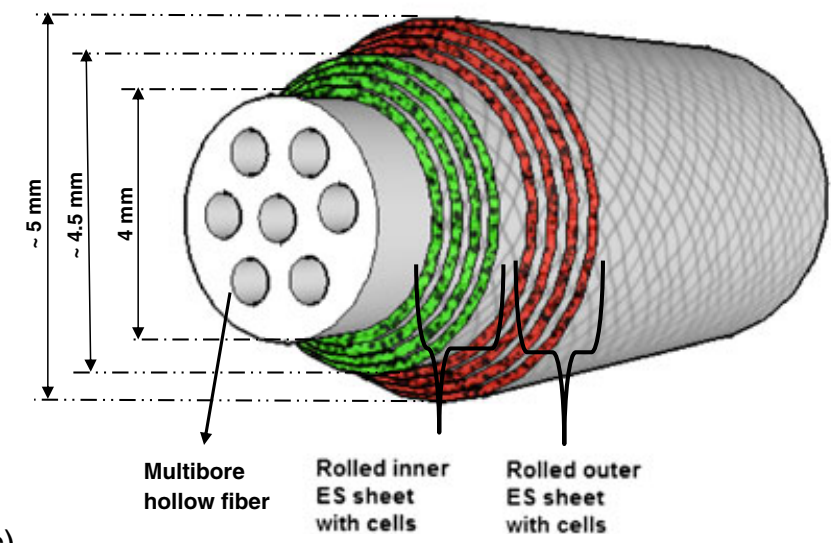

(c)

Figure 2. Scheme of the dynamic perfusion cell culture system (a) perfusion bioreactor setup with various components built inside a controlled cell culture incubator at $37{ }^{\circ} \mathrm{C}$ and $5 \% \mathrm{CO}_{2}$ (b) cell-ES sheet rolled on multibore $\mathrm{HF}$ module mounted within glass bioreactor with side ports (flow through $\mathrm{HF}=1 \mathrm{ml} / \mathrm{min}$ maintained at $50 \mathrm{mbar}$ transmembrane pressure and flow around MES construct = $0.26 \mathrm{ml} / \mathrm{min}$ ) and (c) cross-section of multilayer construct 
the bioreactor using long $(\sim 1.5 \mathrm{~m})$ gas permeable silicon tubing. The peristaltic pump used different tube diameter for controlled medium volumetric flow rate. Pressure sensor (Sper scientific pressure sensor with interchangeable transducers, Applikon analytical) and control valves (flow control valves, Festo B.V., Delft, The Netherlands) were used to regulate the input trans-membrane pressure of the medium across the HF. The various parts of bioreactor were sterilized by autoclaving before each experiment. Fresh medium was perfused in single-pass and the stream leaving the bioreactor was collected as waste. When the system reached the steady state, the stream leaving the bioreactor was recycled. Medium samples were collected from the outlet stream to evaluate the glucose depletion and lactate formation using Vitros-DT60 diagnostic slides (Ortho-Clinical diagnostics, Tilburg, The Netherlands).

The bioreactor consisted of MES construct housed in a glass tube of $1.5 \mathrm{~cm}$ diameter and $5 \mathrm{~cm}$ long with two side ports (built in-house) for medium flow and recirculation (Figure 2b). The MES construct was held in the centre of the glass housing by a screw cap and silicon sealant rings mounted on the 8-mm polyethylene tubing at both ends of the multibore HF module (Figure 2b). Two different medium perfusion flow configurations were investigated. 1) Flow through multibore hollow fibre. In this configuration, the pumped medium flowed through the lumen of the multibore HF. The trans-membrane pressure across the fibre was monitored and kept constant at 50 mbar with an average crossflow velocity of $1 \mathrm{ml} / \mathrm{min}$. The permeating medium through the hollow fibre refreshed the medium in the bioreactor and exited through the side ports of the reservoir. 2) Dual flow through multibore hollow fibre and construct. Here, along with the flow via the multibore HF, flow was simultaneously charged from the side ports in a counter-current direction with an average flow rate of $0.26 \mathrm{ml} / \mathrm{min}$. This flow continuously refreshed the medium in the glass tube and around the MES construct. The flow rates were maintained for both flows using a peristaltic pump (8 leads) with different tube diameters. The same medium reservoir was used for both flows to pump medium to the proliferating cells in the bioreactor.

\subsection{Multilayer cell-electrospun (MES) construct analysis}

\subsubsection{Cell viability staining}

Cell viability on the ES sheets was examined using LIVE-DEAD ${ }^{\circledR}$ staining assay (Invitrogen). In fact, after unrolling the ES sheets in separate well plates, the sheets were incubated for $10 \mathrm{~min}$ with $6 \mu \mathrm{M}$ ethidium homodimer and $1 \mu \mathrm{M}$ calcein in PBS solution (LIVE/DEAD Reduced biohazard cell viability kit, Invitrogen). Fluorescent microscopic images of each sheet were scanned in $64(32 \times 2)$ individual images using an automated confocal microscope (BD pathway 435, BD Biosciences) and collaged together to form a single image to visualize cell viability and distribution.

\subsubsection{Cell fixation and staining for light microscopy}

ES sheets were unrolled from the MES construct, samples were washed with PBS and incubated for 30-60 min in $10 \%$ neutral buffered formalin to fixate the cells and again washed with PBS. Subsequently, the sheets were stained with a few drops of $1 \%$ methylene blue staining solution prepared in borax solution for 3-5 min to stain the cells. Next, the sheets were washed with demineralized water to remove excess of staining solution. The stained samples were stored dry until further use for light microscopic analysis. The ES sheet was examined at different sections under a light microscope (Nikon Eclipse E400) and representative images captured using a digital camera (Sony Corporation, Japan) and Matrix Vision software (Matrix Vision GmbH, Oppenweiler, Germany).

\subsubsection{Cell proliferation assay}

The DNA concentration per ES sheet after 7 days was used as an indication for cell proliferation. The samples to be assayed were washed with PBS, cut in half and stored at $-85^{\circ} \mathrm{C}$. Before performing the DNA assay, the samples were allowed to attain room temperature, sliced into small pieces and immersed completely in cell lysis buffer. Quantification of total DNA per sheet (standard deviation of 5 different samples) was measured according to the manufacturer's protocol (CyQuant Cell Proliferation Assay Kit, Invitrogen) using a fluorescent plate reader (Perkin Elmer).

\subsubsection{Pre- labelled multilayer cell-electrospun construct}

To study the migration of cells within the MES construct, pre-seeded cells on the ES sheets were pre-labeled with lypophilic tracers (Molecular Probes, NY, USA) for long term cellular labeling. The inner ES sheet (close to the $\mathrm{HF}$ ) was seeded with cells labeled green using CM-DiO (3,3'-dioctadecyloxacarbocyanine per chlorate) and the outer sheet with cells labeled red using CM-DiI (1,1'dioctadecyl -- 3,3,3',3'-tetramethylindocarbocyanine per chlorate) dyes (see illustration in Figure 2c). Pre-labeling was carried out according to manufacturer protocols. Briefly, trypsinized cells were resuspended at $2 \times 10^{6} / \mathrm{ml}$ in PBS to which $4 \mu \mathrm{L}$ of $4 \mu \mathrm{M}$ concentration of respective dyes were added and incubated for $5 \mathrm{~min}$ at $37^{\circ} \mathrm{C}$ and subsequent $15 \mathrm{~min}$ at $4^{\circ} \mathrm{C}$ to reduce endocytosis while labeling. The labeled cells were washed with excess PBS and resuspended in medium before seeding on ES sheets.

Dynamic culture at 3 and 7 days was carried out in the dual flow bioreactor as explained earlier. Images of the cross-section of the MES construct at 3 and 7 days were taken using BD pathway 435 (BD Biosciences). In fact, $49(7 \times 7)$ individual images were taken and collaged together to form one complete image of the sectioned MES construct. 


\subsection{Statistical analysis}

For all the experiments, three to five samples were used $(n=3-5)$ unless otherwise specified. Values were reported as the average of all the samples and the error was reported as the standard error of the mean. Statistical significance was calculated using the double-tailed t-test at $p<0.05$.

\section{Results and discussion}

\subsection{Fabrication and characterisation of electrospun sheets}

PLLA solution dissolved in 1,3 dioxane was successfully electrospun using the in-house built electrospinning setup. SEM images were made to determine the surface topography and fibre diameter (Figure 3). The sheets were viewed under SEM after sputter coating with gold. The influence of various spinning parameters such as polymer concentration, flow rate and distance between needle and collector were studied, whereas the applied voltage was kept constant at $15 \mathrm{KV}$ for all cases.

The fabrication showed that below $12 \mathrm{wt} \%$ PLLA polymer concentrations, bead formation occurred (Figure 3). The fibre diameter increased with increasing polymer concentration due to increasing viscosity and lower conductivity of the polymer solution (Figure $4 \mathrm{a}$ at constant flow rate $-2 \mathrm{ml} / \mathrm{hr}$, collector height $-20 \mathrm{~cm}$ ).
The influence of polymer flowrate through the capillary needle ranging between 0.5 to $10 \mathrm{ml} / \mathrm{hr}$ was also studied for different polymer concentrations at constant collector distance of $20 \mathrm{~cm}$. The fibre diameter of the ES sheet increased with increasing flowrates for 13 and $15 \mathrm{wt} \%$ PLLA solutions (Figure 4b) due to large droplet formation (also called Taylor cone) (Ni et al., 2008) at the tip of the capillary needle due to surface tension and the force of the electrostatic field. The fibre diameter obtained with $12 \mathrm{wt} \%$ PLLA solution was similar for all flow rates (Figure 4b) due to the higher solution conductivity, but increasing flow rate influenced bead formation within the mesh. Furthermore, the influence of collector distance was tested for 12 and $15 \mathrm{wt} \%$ polymer concentration. Figure $4 \mathrm{c}$ represents the fibre diameter of ES meshes collected at 15, 20 and $25 \mathrm{~cm}$ between needle tip and collector plate. Increasing collector distance influenced solvent evaporation during the time of flight before collecting on the collector plate, hence smooth and round fibres were formed with increasing collector distance. For both polymer concentrations, the standard deviation of fibre diameter decreased with increasing distance but the average diameter increased with increasing collector distance due to lower electrostatic force experienced by the Taylor cone to overcome the surface tension of the polymer solution.

Considering the above results, the sheets prepared using $12 \mathrm{wt} \%$ PLLA solution concentration at $2 \mathrm{ml} / \mathrm{h}$ flow rate and $20 \mathrm{~cm}$ air gap were considered the optimum, having fibre diameter $2.5 \pm 2 \mu \mathrm{m}$ and hence all cell culture experiments were carried out using these meshes collected

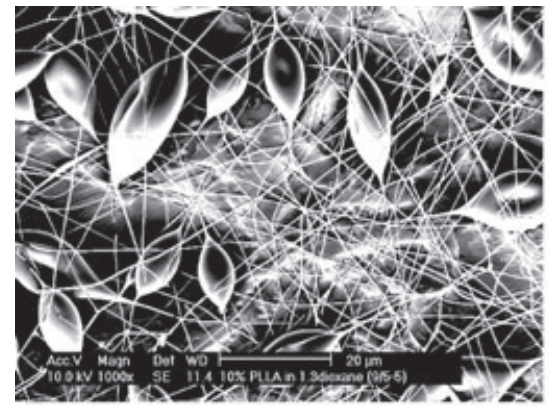

(a) 10 wt\% PLLA

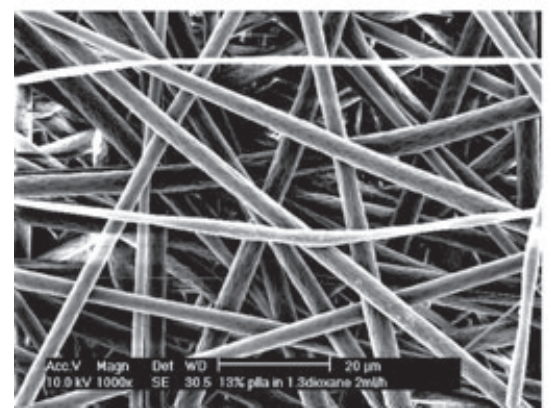

(c) $13 \mathrm{wt} \%$ PLLA

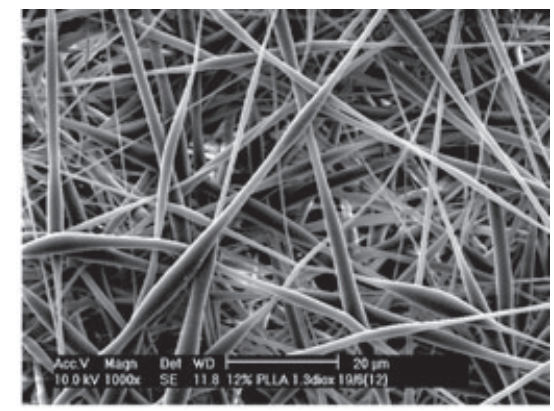

(b) 12 wt\% PLLA

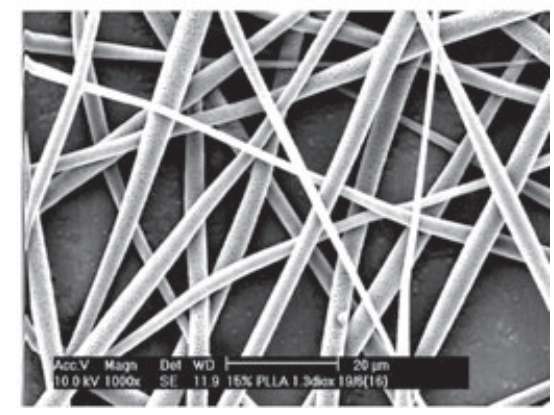

(d) $15 \mathrm{wt} \%$ PLLA

Figure 3. SEM images of ES sheet spun at different PLLA solution concentration (a) $10 \mathrm{wt} \%$ (bead formation due to low viscosity and high electrostatic pull), (b) $12 \mathrm{wt} \%$, (c) $13 \mathrm{wt} \%$, and (d) $15 \mathrm{wt} \%$ dissolved in 1,3 dioxane (voltage $=15 \mathrm{KV}$, height $=20 \mathrm{~cm}$, flow rate $=2 \mathrm{ml} / \mathrm{h}$ ) 
(a)

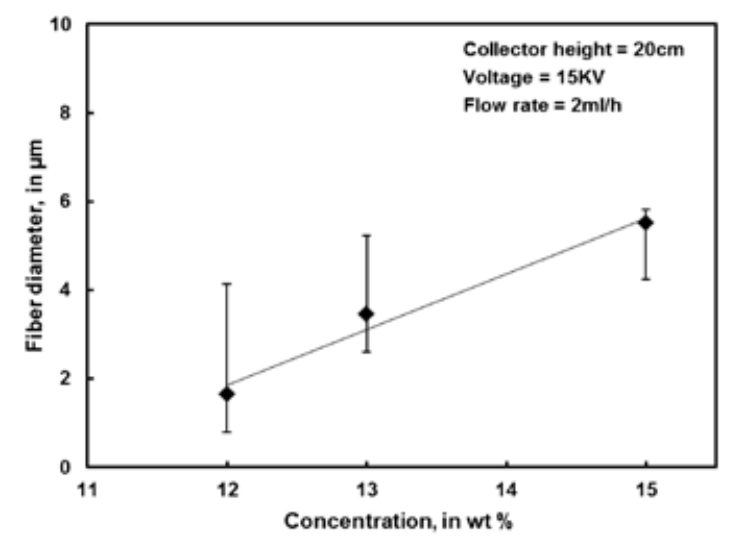

(b)



(c)

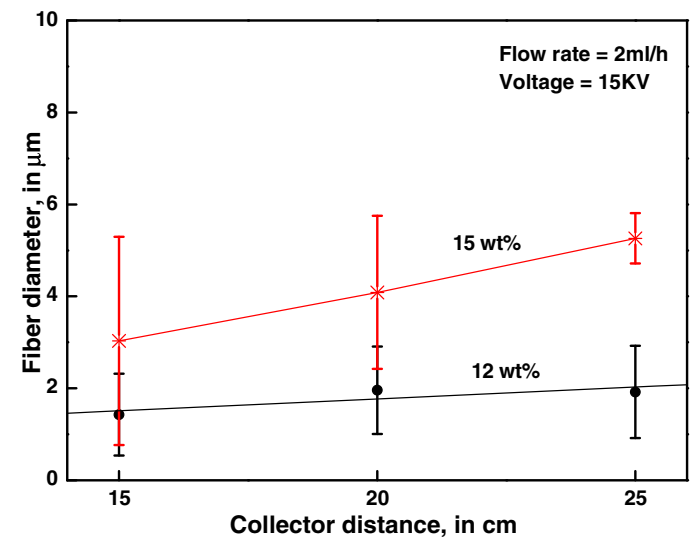

Figure 4. Plot of the influence of electrospinning parameters on fibre diameter: (a) polymer concentration, (b) flowrate and (c) distance between needle tip and collector

for $30 \mathrm{~min}$ on $10 \times 10 \mathrm{~cm}$ electrically grounded collector (aluminium foil). The sheet thickness was approximately $200 \mu \mathrm{m}$ with a porosity of $71 \pm 3 \%$ (measured using pycnometer).

\subsection{Characterisation of multibore hollow fibre membrane}

\subsubsection{Scanning electron microscope}

Figure 5 shows the SEM images of the multibore HF. It consists of seven bores $(0.9 \mathrm{~mm}$ inner diameter) arranged symmetrically to form a single fibre of $4 \mathrm{~mm}$ diameter. This arrangement significantly increased the mechanical stability of the interconnected porous structure. The membrane effective separation layer was present at the inner surface of the lumen supported by open porous support structure. The pores on the outer surface of the hollow fibre were between 0.5 to $3 \mu \mathrm{m}$ so that the fibre wall acted as a barrier and inhibited cell infiltration into the pores of the hollow fibre.

\subsubsection{Clean water and medium permeance}

Figure 6 shows that the clean water flux at varioustransmembrane pressures (0.1-0.25 bar) was linear and no membrane compaction occurred at this pressure range (several cycles of increasing and decreasing pressure flux were tested). The water permeance through the multibore HF was approximately $780 \mathrm{~L} /\left(\mathrm{m}^{2} \mathrm{~h}\right.$ bar) calculated from the slope of the plot in Figure 6.

For cell culturing, the HF should deliver culture medium containing FBS to the cells. FBS is a cocktail of $65 \%$ albumin (molecular weight $\sim 66 \mathrm{kDa}$ ) and other small chain proteins (Baker et al., 1988; Zheng et al., 2006). These proteins may negatively influence the medium permeation by fouling the HF. The maximum allowable pressure in a bioreactor system for tissue engineering application mimicking the physiological condition for cell culture is in between 0.1 to 0.15 bar, corresponding to human diastolic and systolic blood pressure. Hence, we measured the medium transport thought the HF for transmembrane pressure up to 0.1 bar in sterile crossflow filtration set-up. The medium permeance though the HF was almost identical to the clean water flux $\left(\sim 780 \mathrm{~L} /\left(\mathrm{m}^{2} \mathrm{~h}\right.\right.$ bar $)$ (Figure 6), illustrating that the pores of the HF did not foul by the medium proteins and medium transport could be maintained. Our results also suggest that the medium permeance through the HF would be sufficient for multilayer tissue culture of approximately 10 layers of cells in confluence per unit of hollow fibre surface area at transmembrane pressure of 0.05 bar (calculated corresponding 


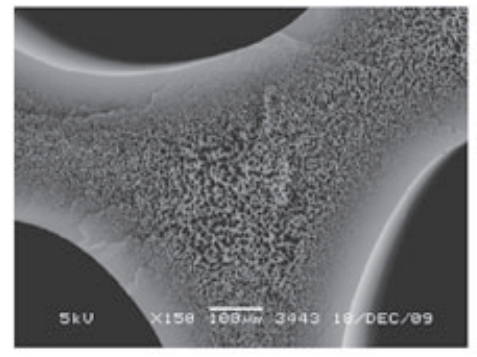

(b) Cross section

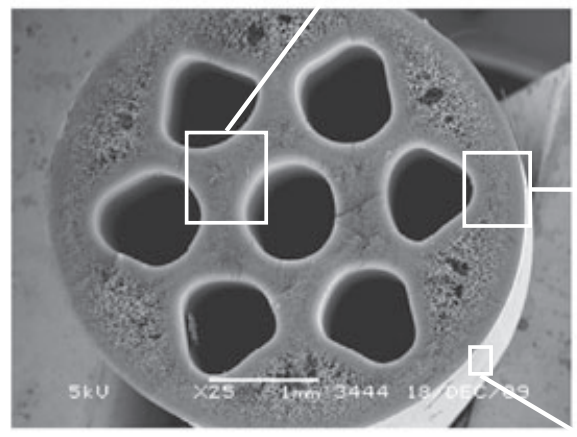

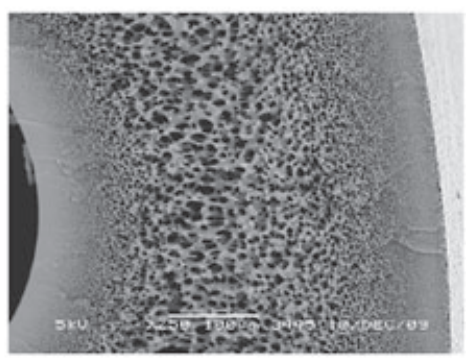

(c) Cross section

(a) Cross section

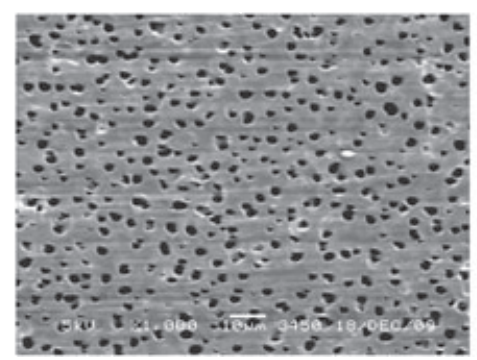

(d) Outer surface

Figure 5. SEM images of multibore hollow fibre showing the symmetric arrangement of 7 bore in single fibre with open surface and porous support structure in-between. Scale bar (a) $1 \mathrm{~mm}$, (b) $100 \mu \mathrm{m}$, (c) $100 \mu \mathrm{m}$, (d) $10 \mu \mathrm{m}$

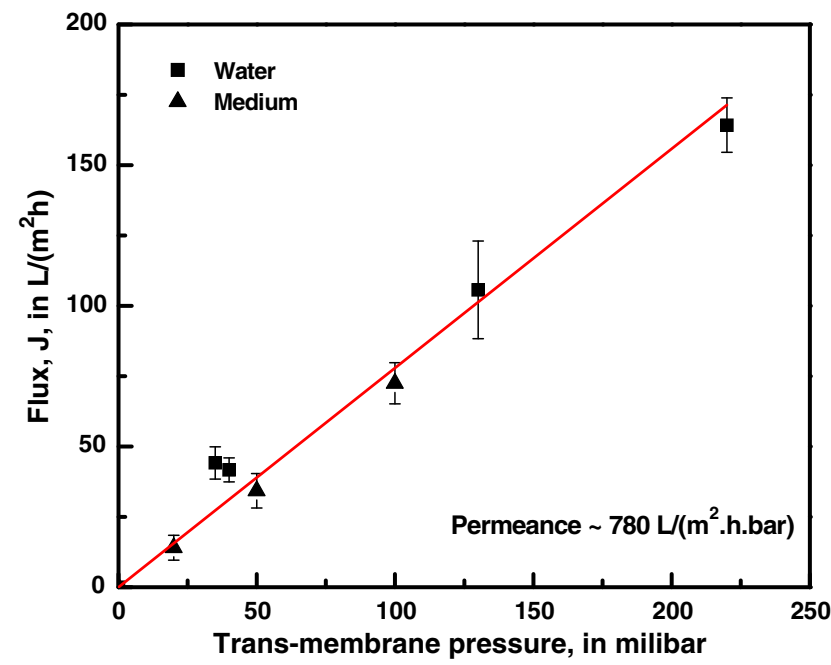

Figure 6. Flux of pure water and culture medium through multibore HF membrane with respect to applied trans-membrane pressure

to the theoretical data for cell consumption (Abdullah et al., 2006; Ye et al., 2006)). In fact, the medium permeated through the HF at steady state was tested for $\mathrm{C} 2 \mathrm{C} 12$ cells culture in T-20 and the results were compared to cell culture with proliferation medium (positive control) and DMEM without FBS (negative control) to evaluate whether there was any difference in proliferation rate due to HF permeation. Figure 7 shows the light microscopic images of C2C12 cells cultured after 1 and 3 days with the respective media refreshed every alternate day. The images show that the proliferation of cells cultured with medium permeated through the HF after 15 and 60 min (Figures 7c and 7d) and standard proliferation medium (Figure 7a) was identical, proving that the fibre did not retain any valuable components of the medium. The rather lower cell proliferation with DMEM medium (without FBS, Figure 7b) illustrates that FBS was essential for high $\mathrm{C} 2 \mathrm{C} 12$ cell proliferation.

\subsection{Bioreactor experiments}

Perfusion bioreactor experiments were carried out with a construct containing approximately eight layers of cell-ES sheet rolled around a multibore HF module. For all 


\begin{tabular}{|c|c|c|c|}
\hline & & 1 day & 3 days \\
\hline (a) & $\begin{array}{l}\text { DMEM + } \\
10 \% \text { FBS } \\
\text { (Normal } \\
\text { Medium) }\end{array}$ & & \\
\hline (b) & $\begin{array}{c}\text { DMEM } \\
\text { (No FBS) }\end{array}$ & & \\
\hline (c) & $\begin{array}{c}\text { Medium } \\
\text { filtered } \\
\text { through HF } \\
\left(1^{\text {st }} 15 \mathrm{~min}\right)\end{array}$ & & \\
\hline (d) & $\begin{array}{c}\text { Medium } \\
\text { filtered } \\
\text { through HF } \\
\text { (After 60min) }\end{array}$ & & \\
\hline
\end{tabular}

Figure 7. Light microscopic image of $\mathrm{C} 2 \mathrm{C} 12$ cells cultured for 1 and 3 days with normal proliferation medium, DMEM without FBS, and medium prefiltered through the multibore HF (seeding density; 3000 cells $/ \mathrm{cm}^{2}$ )

bioreactor experiments, the medium used in the reservoir was pre-conditioned by allowing medium gas exchange via pumping through gas permeable platinum cured silicon tubes built within temperature, $\mathrm{CO}_{2}$ and humidity controlled incubator for at least $12 \mathrm{~h}$. During culture, the medium was maintained with minimum glucose at $17 \pm 0.5 \mathrm{mM}$ and maximum lactate at $6.5 \pm 0.7 \mathrm{mM}$ concentration (compared to fresh medium concentration of $25.1 \pm 0.4 \mathrm{mM}$ and $0.9 \pm 0.3 \mathrm{mM}$, respectively) before refreshing in the reservoir for both static and dynamic culture to avoid the risk of recirculating toxic waste to the proliferating cells.

\subsubsection{Cell viability}

Two different configurations of medium flow through the bioreactor were assessed by carrying out cell culture experiments with medium flow through the multibore HF lumen and dual flow through the HF lumen and through the scaffold itself (Figure 2). For comparison, constructs were also cultured statically in T-flask as control. Figure 8 shows the collaged (64 images, 10x magnification) fluorescent microscopic images of the unrolled ES sheet cultured under static (performed in T-flask) and dynamic conditions in the bioreactor (Figure 2) for 7 days and stained for cell viability (Live-dead assay, Invitrogen). The green colour in these images represents viable cells at different culture conditions.

For the statically cultured samples, cell proliferation varied within the outer and inner sheets (Figure 8a). The outer sheet being directly in contact with medium had viable cells at the outer most edge whereas the cell number decreased as one looks towards the inner edge. The medium diffused through the initial layers but probably the proliferating cells themselves became a barrier for medium diffusion, hence in the middle layers, fewer cells are visible. Similar results with no viable cells can be observed at the outer edge of the inner sheet. Few viable cells at the innermost edge of the inner sheet close to the fibre were due to medium diffusion through the porous walls of the multibore HF (improves medium availability locally), which is in contact with the bulk medium. These results were also confirmed with staining the adherent cells using methylene blue and the cell distribution observed 


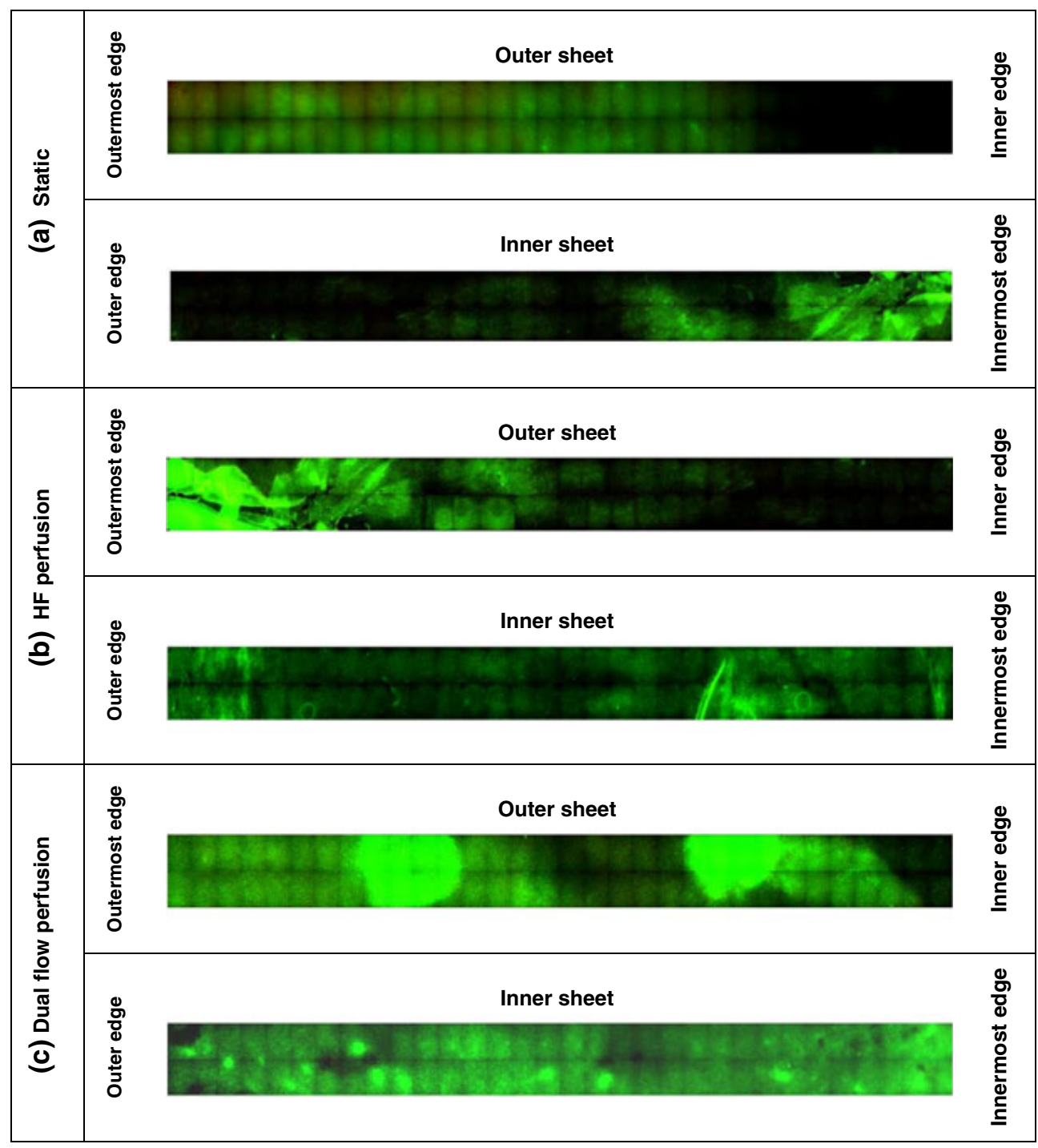

Figure 8. Fluorescent microscopic images of C2C12 cells stained with live-dead assay (CyQuant cell proliferation assay kit, Invitrogen) cultured under static and dynamic conditions for 7 days on MES construct. Each of these images is a collage of 64 images $(2 \times 32)$. Green fluorescent color indicates viable cells

under light microscope. Most of the cells (stained blue) were located at the outer most edge of the outer sheet close to the medium and innermost edge of the inner sheet close to the HF (Figure 9a).

Images of constructs dynamically cultured with flow through the multibore HF lumen show uniform cell proliferation only on the inner sheet close to the HF (Figure $8 \mathrm{~b}$ ). Viable cells on the outer sheet were mostly concentrated on the outermost edge close to the medium. This could be due to irregular and slow refreshing of medium in the surface of the construct. Here, the medium permeated through the fibre could even experience a channelling effect by which stagnant zones within the bioreactor/scaffold could be created, thereby negatively influencing cell proliferation. These results were again confirmed with methylene blue stained images (Figure 9b). The intense blue stain observed at the outermost edge of the outer sheet close to the medium and the innermost edge of the inner sheet close to the fibre illustrates high cell proliferation.
The gradient in dye intensity on the inner sheet as we look from the centre to outer edge suggests lower cell numbers in the inner sheet probably due to improper nutrient diffusion further away from the permeating HF.

The images for the constructs cultured under dual flow showed high cell proliferation on both inner and outer sheets. Higher intensity of green fluorescent colour indicates a higher number of viable cells on both ES sheets. The flow through the scaffold in the counter current direction via the side ports helped refreshing the medium around the construct and improved cell viability and proliferation on the outer sheet. This flow achieved uniform proliferation by refreshing the medium around the 3D construct (from outside) and concealed any channelling of HF permeated medium. The flow via the HF achieved uniform cell proliferation and distribution in the inner layer. Methylene blue stained images of these samples (Figure 9c) showed that the cells completely cover the surface of both the ES sheets and illustrate good cell culture environment across the multilayer 3D construct. 


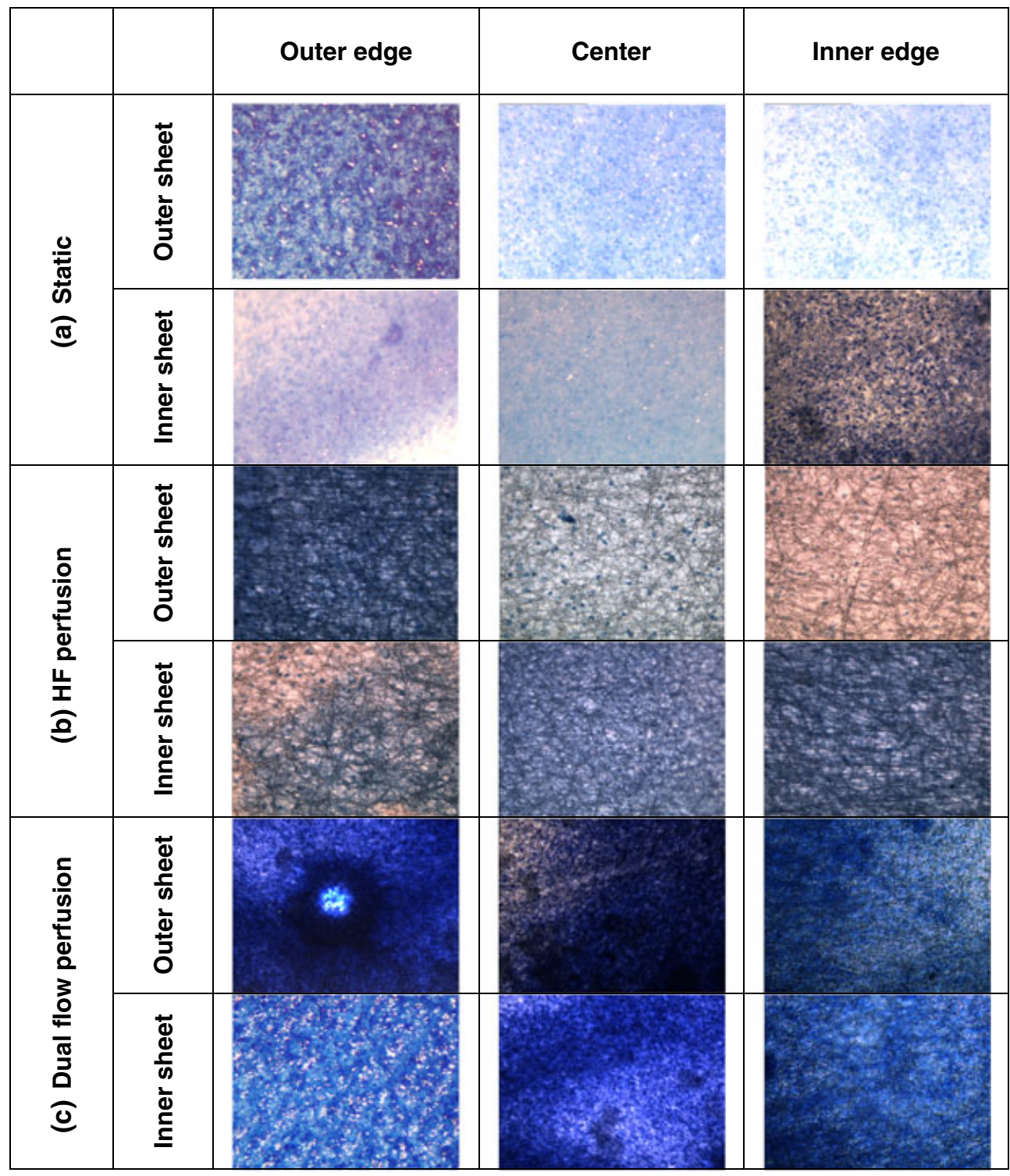

Figure 9. Light microscopic images of methylene blue stained C2C12 cells cultured under static and dynamic culture conditions for 7 days on the multilayer construct ( $4 \mathrm{x}$ magnification). The blue colour indicates adhering cells to the ES sheet and increasing colour intensity indicates cell distribution or cell cluster

\subsubsection{Cell proliferation}

The total DNA concentration (which corresponds to cell number) quantified over the rolled MES cultured for 7 days under static culture in petri dish and dual flow dynamic culture in perfusion bioreactor are presented in Figure 10. An unrolled flat sheet was also cultured under static condition in petri dish as a positive control. To evaluate cell distribution in different parts of the MES, each sheet (inner and outer) was cut in half and analysed separately using CyQuant Cell Proliferation Assay Kit. Figure 10 presents the DNA results of the inner and outer half sheets. For each sheet, five different samples were analysed.

For the unrolled ES sheet cultured statically (positive control), the DNA values were high. In this case, the cells cultured on the sheet were in direct contact with the medium and no oxygen or nutrient diffusion limitations occurred. For the rolled MES construct cultured statically in the petri dish, the DNA content was very low on both sheets (inner and outer sheets) in comparison to the unrolled positive control. This was due to nutrient and oxygen diffusion limitation in the multilayer MES construct. The outer sheet close to the medium had higher DNA values than the inner sheet. This was consistent with the results presented earlier (Figures 8, 9) and other studies (Papenburg et al., 2009) showing that proliferating cells in the outer layer act as barrier to medium or oxygen transport to the inner layer.

The results of the dynamic perfusion show similar DNA content on all four parts of the ES sheets comparable to the positive control. The medium perfusion via the $\mathrm{HF}$ enhanced the nutrient diffusion through the multilayer construct from inside, improving cell proliferation in the middle layers by convective diffusion of nutrients and 


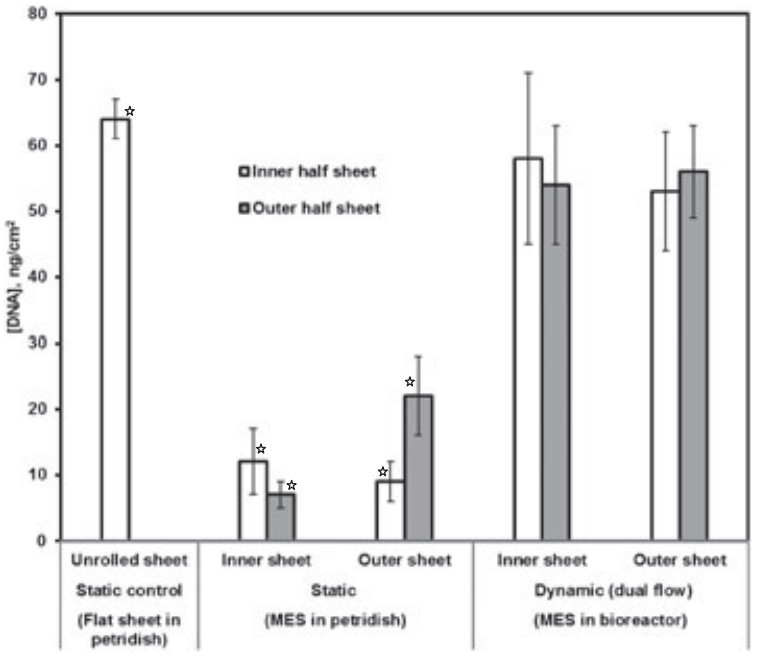

Figure 10. C2C12 cell proliferation within the sheet rolled around multibore HF membrane cultured statically and dynamically for 7 days. Control indicates the flat sheet (unrolled) sample cultured statically in petri dish $[*=$ significant difference against control and statically cultured 3D construct $(p<0.05)$, error-bars indicate standard deviation]

oxygen. The flow from the side ports in the counter current direction refreshed the medium around the multilayer construct and improved cell growth on the construct periphery. Overall, the DNA data for dynamic culture experiment confirmed that dual flow is the best configuration to achieve uniform cell growth across different layers of MES construct.

\subsubsection{Cell migration}

For the MES construct cultured in dual flow perfusion bioreactor, cell migration within multilayer ES sheets was studied by seeding pre-labeled C2C12 cells with two different lypophilic tracers: CM-DiO green for cells in the inner sheet and CM-DiI red for cells in the outer sheet. After culturing for 3 and 7 days, the samples were analysed using fluorescent microscopy. Images were made at corresponding excitation and emission filter wavelengths for each dye and finally merged to observe any cell overlapping, which would suggest cells migration.

Figure 11 presents a collage $(7 \times 7=49$ images $)$ of fluorescent images of MES construct in cross-section and in sections along the construct. Images of cells cultured for 3 days showed distinct layers of red cells in the outer sheet and green cells in the inner sheet. The assembly of distinctly labelled cells in the different layers showed that by using this our concept, one can incorporate multiple cell types in different layers. The

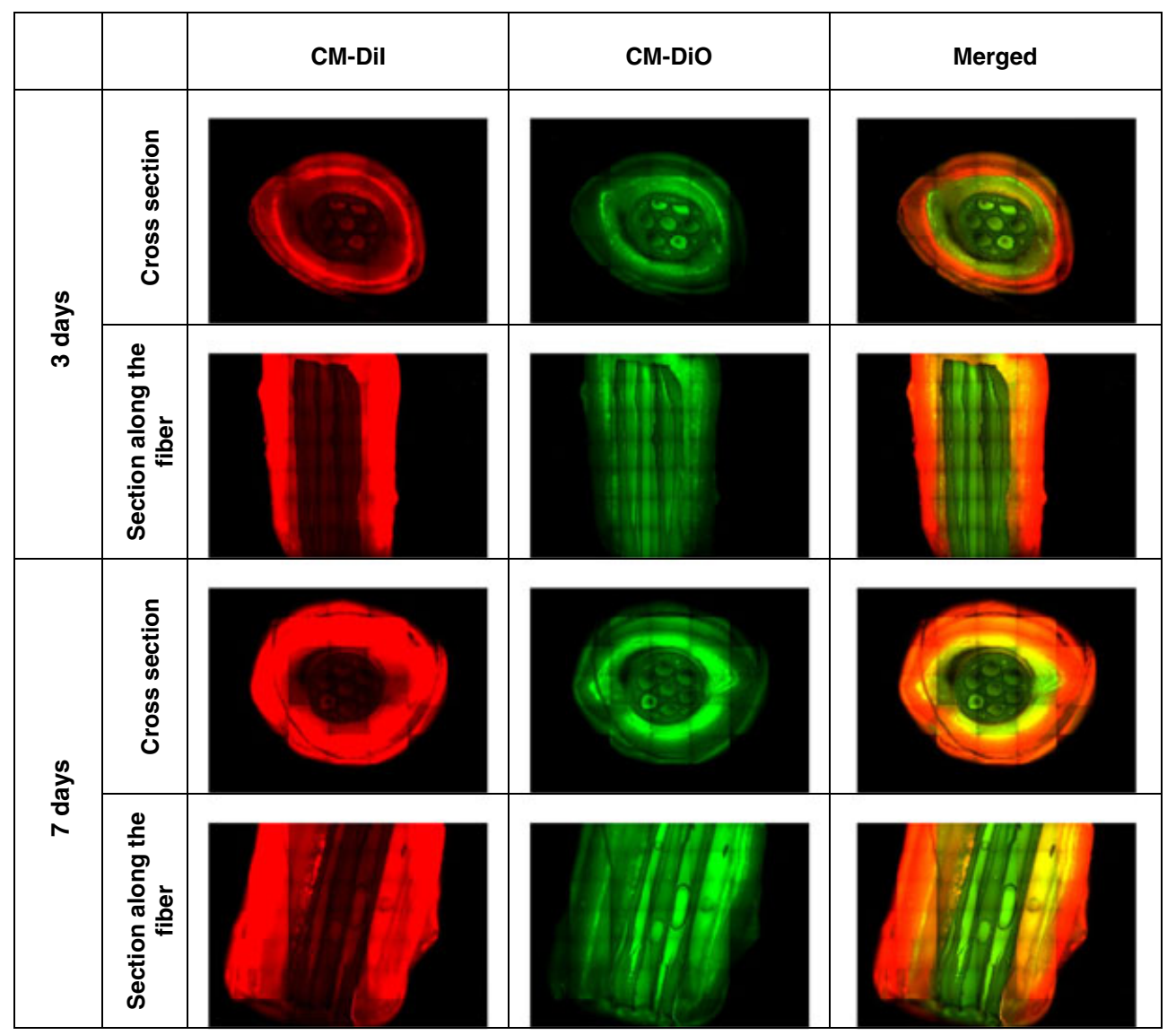

Figure 11. Fluorescent microscopic images of pre-labeled C2C12 cells cultured dynamically on the construct with dual flow for 3 and 7 days. The inner ES sheet close to the HF was seeded with cells labelled green using CM-DiO (3,3'-dioctadecyloxacarbocyanine per chlorate) and the outer sheet with cells labeled red using CM-DiI (1,1'-dioctadecyl--3,3,3',3'-tetramethylindocarbocyanine per chlorate) dyes. Each of these images is a collage of 49 images $(7 \times 7)$. Yellow color in merged images is caused by overlaping of red and green labeled cells due to cell migration within the scaffold layers 
thickness of each layer can be controlled by the length of the corresponding ES sheet. At 7 days, the images suggest migration of red cells from the outer sheet to inner sheet illustrated by development of yellow colour when overlapping of red and green cells in merged image (Figure 11). The pore size of the ES sheet was $30 \pm 10 \mu \mathrm{m}$ determined via SEM image analysis, which allowed cell migration within the MES construct. This migration of cells within MES construct was probably due to better nutrient availability in the inner layer due to the perfusion through the HF. Migration could also be stimulated by the small negative pressure difference created within the MES construct due to medium flowing through the multibore HF. More experiments using different medium flow rates and medium concentrations should be carried out to understand better the phenomena. Besides, by using sheets with different pore sizes, one could manipulate cell migration within layers allowing studies of cell-cell interaction in this 3D environment.

\section{Conclusions and outlook}

This study showed the development of a multilayer scaffold by combing ES sheets with a multibore hollow fibre membrane. Static culture experiments showed that critical nutrient limitations occurred within the first two layers, with the proliferating cells themselves acting as barrier for nutrient diffusion. The dynamic perfusion through the multibore HF lumen combined with counter current perfusion around the construct led to high cell proliferation and uniform cell distribution within the construct.

Our future work will focus on development of specific multilayer tissues using the proposed concept. In fact, the multibore hollow fibre could be utilized for delivering various agents to the cells in a controlled and site-specific manner. For example, one could create nutrient and/or growth factor gradients within the scaffold by delivering different media through each bore or by delivering drugs or other components to the cells at a specific site by utilizing perfusion via specific fibre bores. This system could also be used by the pharmaceutical industry for initial toxicity tests at cellular level, thereby reducing the need for animal tests. This device can further be extended to culture large cell sheets as in vitro skin substitutes, multi-cellular vascular grafts of required diameter, secretion of body fluids, e.g., bile, pancreatic fluids, etc.

\section{Acknowledgements}

The authors would like to acknowledge the financial support from Technology Foundation STW (Project number - TKG. 6716). We also thank JB Bennink for assistance with the artwork.

\section{References}

Abdullah NS, Das DB, Ye H et al. 2006; 3D bone tissue growth in hollow fibre membrane bioreactor: Implications of various process parameters on tissue nutrition. Int $J$ Artif Organs 29(9): 841-851.

Abdullah NS, Das DB. 2007; Modelling nutrient transport in hollow fibre membrane bioreactor for growing bone tissue with consideration of multi-component interactions. Chem Eng Sci 62(21): 5821-5839.

Baiguera S, Birchall MA, MacChiarini P. 2010; Tissue-engineered tracheal transplantation. Transplant 89(5): 485-491.

Baker H, DeAngelis B, Frank O. 1988; Vitamins and other metabolites in various sera commonly used for cell culturing. Cell Mol Life Sci 44(11): 1007-1010.

Brayfield C, Marra K, Rubin JP. 2010; Adipose stem cells for soft tissue regeneration. Handchir Mikrochir Plast Chir 42(2): 124-128.

De Bartolo L, Morelli S, Rende M et al. 2007; Human hepatocyte morphology and functions in a multibore fiber bioreactor. Macrom Biosci 7(5): 671-680.

De Bartolo L, Salerno S, Curcio E et al. 2009; Human hepatocyte functions in a crossed hollow fiber membrane bioreactor. Biomaterials 30(13): 2531-2543.

Ellis MJ, Chaudhuri JB. 2007; Poly(lactic-coglycolic acid) hollow fibre membranes for use as a tissue engineering scaffold. Biotechnol Bioeng 96(1): 177-187.

Fukuhara S, Tomita S, Yamashiro S et al. 2003; Direct cell-cell interaction of cardiomyocytes is key for bone marrow stromal cells to go into cardiac lineage in vitro. $J$ Thorac Cardiovasc Surg 125(6): 1470-1480.

Goldstein AS, Christ G. 2009; Functional tissue engineering requires bioreactor strategies. Tissue Eng Part A 15(4): 739-740.

Janssen FW, Oostra J, Van Oorschot A et al. 2006; A perfusion bioreactor system capable of producing clinically relevant volumes of tissue-engineered bone: In vivo bone formation showing proof of concept. Biomaterials 27(3): 315-323.

Janssen FW, Van Dijkhuizen-Radersma R, Van Oorschot A et al. 2010; Human tissue-engineered bone produced in clinically relevant amounts using a semiautomated perfusion bioreactor system: A preliminary study. $J$ Tissue Eng Regen Med 4(1): 12-24.

Ju YM, Choi JS, Atala A et al. 2010; Bilayered scaffold for engineering cellularized blood vessels. Biomaterials 31(15): 4313-4321.

Kleinman HK, Philp D, Hoffman MP. 2003; Role of the extracellular matrix in morphogenesis. Curr Opin Biotechnol 14(5): 526-532.

Langelaan MLP, Boonen KJM, Polak RB et al. 2010; Meet the new meat: tissue engineered skeletal muscle. Trends Food Sci Technol 21(2): 59-66.

Martin I, Wendt D, Heberer M. 2004; The role of bioreactors in tissue engineering. Trends Biotechnol 22(2): 80-86.

Morelli S, Salerno S, Piscioneri A et al. 2010; Influence of micro-patterned PLLA membranes on outgrowth and orientation of hippocampal neurites. Biomaterials 31(27): 7000-7011.

Neves NM, Campos R, Pedro A et al. 2007; Patterning of polymer nanofiber meshes by electrospinning for biomedical applications. Int J Nanomed 2(3): 433-438.

$\mathrm{Ni}$ L, Xiao-Hong Q, Ling L et al. 2008; The effects of spinning conditions on the morphology of electrospun jet and nonwoven membrane. Polymer Eng Sci 48(12): 2362-2366.

Papenburg BJ, Liu J, Higuera GA et al. 2009; Development and analysis of multi-layer scaffolds for tissue engineering. Biomaterials 30(31): 6228-6239.

Pei M, Solchaga LA, Seidel J et al. 2002; Bioreactors mediate the effectiveness of tissue engineering scaffolds. FASEB $J$ 16(12): 1691-1694.

Peterson L, Minas T, Brittberg M et al. 2000; Two-to 9-year outcome after autologous chondrocyte transplantation of the knee. Clin Orthop Relat Res (374): 212-234.

Pham QP, Sharma U, Mikos AG. 2006a; Electrospun poly ( $\varepsilon$-caprolactone) microfiber and multilayer nanofiber/ microfiber scaffolds: Characterization of scaffolds and measurement of cellular infiltration. Biomacromolecules 7(10): 2796-2805.

Pham QP, Sharma U, Mikos AG. 2006b; Electrospinning of polymeric nanofibers for tissue engineering applications: A review. Tissue Eng 12(5): 1197-1211. 
Porter B, Zauel R, Stockman H et al. 2005; 3-D computational modeling of media flow through scaffolds in a perfusion bioreactor. $J$ Biomech 38(3): 543-549.

Reneker DH, Yarin A, Zussman E et al. (2006). Nanofiber manufacturing: Toward better process control. Polymeric Nanofibers. AC Society, American Chemical Society. 918: 7-20.

Sala FG, Kunisaki SM, Ochoa ER et al. 2009; Tissue-engineered small intestine and stomach form from autologous tissue in a preclinical large animal model. J Surg Res 156(2): 205-212.

Stahl A, Wenger A, Weber H, et al. 2004; Bi-directional cell contact-dependent regulation of gene expression between endothelial cells and osteoblasts in a threedimensional spheroidal coculture model. Biochem Biophys Res Commun 322(2): 684-692.

Stamatialis DF, Papenburg BJ, Girones M et al. 2008; Medical applications of membranes: Drug delivery, artificial organs and tissue engineering. $J \mathrm{Membr}$ Sci 308(1-2): 1-34
Stevens MM, George JH. 2005; Exploring and engineering the cell surface interface. Science 310(5751): 1135-1138.

Theron SA, Zussman E, Yarin AL. 2004; Experimental investigation of the governing parameters in the electrospinning of polymer solutions. Polymer (Guildf) 45 (6): 2017-2030

Tuzlakoglu K, Bolgen N, Salgado AJ et al. 2005; Nano- and micro-fiber combined scaffolds: A new architecture for bone tissue engineering. J Mater Sci Mater Med 16(12): 1099-1104.

Vaz CM, van Tuijl S, Bouten CVC et al. 2005 Design of scaffolds for blood vessel tissue engineering using a multi-layering electrospinning technique. Acta Biomater 1(5): 575-582.

Wendt D, Riboldi SA, Cioffi M et al. 2009; Potential and bottlenecks of bioreactors in 3D cell culture and tissue manufacturing. Adv Mater 21(32-33): 3352-3367.

Wnek GE, Carr ME, Simpson DG et al. 2003; Electrospinning of nanofiber fibrinogen structures. Nano Lett 3(2): 213-216.

Woodfield TBF, Van Blitterswijk CA De Wijn $J$ et al. 2005; Polymer scaffolds fabricated with pore-size gradients as a model for studying the zonal organization within tissue-engineered cartilage constructs. Tissue Eng 11(9-10): 1297-1311.

Yang X, Shah JD, Wang H. 2009; Nanofiber enabled layer-by-layer approach toward three-dimensional tissue formation. Tissue Eng Part A 15(4): 945-956.

Ye H, Das DB, Triffitt JT et al. 2006; Modelling nutrient transport in hollow fibre membrane bioreactors for growing threedimensional bone tissue. $J \mathrm{Membr} \mathrm{Sci}$ 272(1-2): 169-178.

Zhang W, Abukawa H, Troulis MJ et al. 2009; Tissue engineered hybrid tooth-bone constructs. Methods 47(2): 122-128.

Zheng X, Baker H, Hancock WS et al. 2006; Proteomic analysis for the assessment of different lots of fetal bovine serum as a raw material for cell culture. Part IV. Application of proteomics to the manufacture of biological drugs. Biotechnol Prog 22(5): 1294-1300.

Zussman E, Theron A, Yarin AL. 2003; Formation of nanofiber crossbars in electrospinning. Appl Phys Lett 82(6): 973-975. 